\title{
ACKNOWLEDGMENTS AND A NOTE ON THE COVER ART
}

\begin{abstract}
$\bigwedge$ S in the earlier volumes of this anthology, we are deeply indebted Ato numerous literary scholars, poets, librarians, historians, and anthologists, many of whose names appear in our notes and "Further Reading" selections. We also thank our students at the University of California, Riverside, Washington State University, and Hartwick College for their eagerness to explore the poetry with us. We are grateful to our colleagues as well for their support and encouragement.
\end{abstract}

As always, our most heartfelt thanks go to Leslie Mitchner, our wonderful editor at Rutgers, for her enthusiasm, professionalism, imagination, wisdom, and patience. We have reason to be especially grateful for that last quality this time around. We are also grateful to the rest of the staff at the press, particularly Katie Keeran and Bryce Schimanski. For their great and generous help in arranging for our use of Pierre Daura's painting The Love of the 3 Oranges (1953-60) as our cover art, we especially thank Martha Daura and Tom Mapp as well as Lisa Fischman, director of the Davis Art Museum at Wellesley College, and the talented Sandra Hachey of the museum staff who discovered that Daura had painted more than one version of the cover art. We are grateful, as always, to Melody Lacina for her expert copy-editing. We also thank Carol Bifulco of BookComp.

Steven Gould Axelrod thanks his remarkable research assistant, Anthony Randall, who solved many a riddle and shared with him the experience of permissions dilemmas and victories. He thanks Hong Jig Rim, who performed expert research assistance at an earlier stage of composition. He is grateful to the librarians at the Tomás Rivera Library and the computer specialists at the University of California, Riverside, for their wise counsel, and he thanks the university's Research Committee for financial support. He thanks the following poets, scholars, and lovers of the arts for their invaluable advice and help: Elmaz Abinader, Rae Armantrout, Doris Awad, Charles Bernstein, Frank Bidart, Alicia Contreras, Liam Corley, Fred Courtright, Catherine Cucinella, Amy Gerstler, Callie Gladman, Jeffrey Gray, Bill Ehrhart, the late Emory Elliott, Lyn Hejinian, Tim Hunt, Frank Kearful, Lisette Ordorica Lasater, Gerald McCarthy, Bill Mohr, the late Kathryn O'Rourke, Marjorie Perloff, Amy Moorman Robbins, Jan Roselle, Maurya Simon, Cathy Song, Elizabeth Spies, Kathleen Spivack, 
Craig Svonkin, Paul Tayyar, Mitsuye Yamada, Guojing Yang, and John Yau. Finally, he thanks Rise B. Axelrod, Jeremiah B. C. Axelrod, Melissa Axelrod, and Lil Delcampo for intellectual stimulation, emotional support, and more; and he welcomes Amalia and Sophie Axelrod-Delcampo into the world.

Camille Roman wishes to acknowledge Washington State University's timely financial support from Douglas Epperson, dean of the College of Liberal Arts, and George Kennedy, chair of the Department of English as well as the assistance of Annette Bednar and Assistant Dean Paul Phillip. Erich Lear, former dean of the College of Liberal Arts, and Victor Villaneuva, former chair of the Department of English, also have been supportive. Roman thanks her university colleagues for their collegiality and hospitality - especially Nic and Karen Kiessling. Also, for their support, Jana Argersinger, Susan Armitage, David Barnes, Ann Berry, Paul Brians, Joan Burbick, Donna Campbell, Peter Chilson, Paula Coomer, Richard Domey, Paula Elliott, Diane Gillespie, Lynn Gordon, Alex Hammond, Barbara Hammond, Elwood Hartman, Polly Hartman, Desiree Hellegers, Tim Hunt, Virginia Hyde, Linda Kittel, Alex Kuo, Buddy Levi, Cami Levi, Stan Linden, Luci Linden, Allison Llevenseller, Michael Llevenseller, Susan McLeod, Rory Ong, Leonard Orr, T.V. Reed, Augusta Rohrbach, Marian Sciachitano, Carol Siegel, Elizabeth Siler, Jerrie Sinclair, Barbara Sitko, Jan Slaybaugh, Richard Slaybaugh, Susan Spurlock, Noel Sturgeon, Al von Frank, Jane von Frank, and Mary Wack. She is grateful to Meghan Wiley as well as Allison Llevenseller and the staff at the Holiday Inn Express in Pullman, Washington, who gave her a cherished space for working on this volume-as well as Debra Royer, at the Crumpacher Family Library, Portland (Oregon) Art Museum, for her inspiring reading room there and archival talents.

For their energizing research support, she thanks her former students, especially Laura Gruber, but also Naomi Allen, Mary Anderson, Christy Kord, Lee Maguire, Jason Miller, Drew Piper, and Patti Ver Straat as well as her poetry and culture classes at Washington State University from 2000 to 2008.

Roman expresses her deep gratitude to Brown University, especially Kevin McLaughlin, dean of the faculty, and Carolyn Deane, senior associate dean of the faculty, for offering her a visiting scholar appointment. She also wishes to thank the Department of English, especially the generous Acting Chair Stephen Foley and its excellent staff members Marilyn Netter and Lorraine Mazza, as well as the talented Rosemary Cullen of the John Hay Library staff.

Roman is grateful to Filipino-American Studies scholar Jane Sarmiento Schwab, who worked with great patience and knowledge alongside her as an assistant editor on the Filipino and Filipino-American cultural and poetry scholarship. Both Roman and Schwab wish to acknowledge the following for their invaluable contributions to this volume. We are deeply grateful to Tom Bolling, Odegaard Undergraduate Library, University of Washington; James Stack, 
Special Collections Division, University of Washington; Morgen MacIntosh Hodgetts, DePaul University; and David Pavelich, University of Chicago. We are also especially indebted to an extraordinary circle of scholars, writers, and poets at the University of Hawaii at Manoa that includes, but is not limited to, Teresita Ramos, founder of the Filipino and Phillipine Literature Program, Ruth Mabanglo, coordinator, Amy Agbayani, Nina Agbayani, Richard and the late Nena Benton, and Aleli and the late Stan Starosta. Equally important are the following: Delia Aguilar, Nick Carbo, Jonathan Chua, John Cowen, Isagani R. Cruz, Reme Grefalda, Luisa Igloria, Fatima Lim-Wilson, Linda Nietes, Lorena O’English, David Romtvedt, E. San Juan, Jr., Eileen Tobias, Timothy Yu, and Nelly and Cesar Zamora.

For their remarkable assistance in the annotations for "The Ghost of Soulmaking," Roman wishes to thank Michael Harper and Ruth Heimann Oppenheim for their generosity and wisdom-and Claudia Oppenheim Cameron, Jeffrey Oppenheim, and Selma Moss-Ward for their support.

For sharing their talents and interests in the arts generously as she worked on volume three, Roman wishes to thank her husband Chris D. Frigon with great affection first and foremost. She also is grateful to Roger Allen and Marie Jones, Sandra Barry, Scott Berg, Daria Bessom, Roger Bessom, Jamie Bhatty, Mutlu Blasing, Courtney Carter, Dottie Chidester, Martha Cutter, Suzanne del Gizzo, Scott Donaldson, Cheryll Faust, Richard Flynn, the late Gerald Frigon and family, Jay and Adrian Glasson, Laura Glenn and family, Lorrie Goldenssohn, Greta and the late Doris Gustafson, Philip Hansen, Hillard Howard, Andi John and family, Dorothy and Bob Johnson and family, Connie Kirk, Nick Kreofsky, Alexia, Jim, and Rick Liebenow, Freddi Lipstein, Eleanor and the late Bob Lowry, the late Bill Maloof, Rajamma Matheu, June and Jim May and family, Jerry McCubbin and Judi McGavin, George Monteiro, Mary Nichols, Pat O'Brien and family, Annette O'Donnell, the late Walter Oppenheim, Peter Papulis and family, Allison Reeves and family, the Jeff Reingolds, the late Harold Reisner, Julie Richie, Donna Riley and family, Bob and Betsy Roman and the Sherricks, Nikki Roman-Bhatty and the Viventis, Marilyn Roman and family, Mary Roman and family, Richard Romiti and family, Karen Skoog, Tori Smith, Frank and Michael Suchomel, the late Darryl Thierse, the late (Elizabeth) Ann (Roper) (Hart) Whitsell, Phyllis Wojciechowski, Susanne Woods, Patricia Yeager, and Ellie Zuckow.

Thomas Travisano wishes to thank research assistants Stevens Van Duzer and Zachary Tilfer, his students at Hartwick College, for their dedicated and enthusiastic work in support of this project. He thanks the reference department at the Hartwick College Library. He is also grateful to the Board of Trustees of Hartwick College and the Office of Academic Affairs for their generous and ongoing support, particularly through a Faculty Research Grant and a Wandersee 
Scholar in Residence Award that supported work on this volume. He thanks his Hartwick classes, particularly in Contemporary American Literature and Four Modern American Poets, for their excellent questions and inquiring attitude. Most of all, he thanks his wife, Elsa Travisano, for her computer expertise and literary judgment as well as for her resilience, patience, good humor, and good counsel.

The cover art of this volume is a reproduction of The Love of the 3 Oranges, painted by Pierre Daura between 1953 and 1960. Daura (1896-1976) was born on the Spanish island of Minorca, grew up in Barcelona, Catalonia (a region of Spain), and lived for many years in Paris. His Spanish citizenship was revoked after he fought with the anti-fascist forces in the Spanish Civil War. While he and his family were visiting Virginia in 1939, World War II broke out, preventing their return to France. Daura lived the rest of his life in Virginia and became an American citizen. The Love of the 3 Oranges, painted in oils, is notable for its fluidity, motion, and color-qualities that can be inferred in many of the poems in this anthology. The oranges in the painting are abstracted, and they appear to resemble human figures. Their ambiguity also seems appropriate to the poetry of this period. Daura's daughter Martha has told us that her father worked on his art while listening to music. He painted this piece, for example, while listening to the Sergei Prokofiev opera, The Love for Three Oranges. The painting, therefore, includes qualities of musicality, visuality, and intertextuality, as do the poems in this volume. 